\title{
Modelling the feed mix for poultry production, the case of Adama Musa farms, in Ghana
}

\author{
S. K. Amponsah ${ }^{2}$, D. Otoo ${ }^{1}$, A. K. Peprah ${ }^{2}$, S. D. Ampofo ${ }^{2}$ \\ ${ }^{1}$ Department of Mathematics, University of Energy and Natural Resources, Sunyani \\ ${ }^{2}$ Department of Mathematics, Kwame Nkrumah University of Science and Technology,Kumasi, Ghana \\ *Corresponding author E-mail: dominicotoo@ rocketmail.com
}

Copyright $\odot 2015$ D. Otoo et al. This is an open access article distributed under the Creative Commons Attribution License, which permits unrestricted use, distribution, and reproduction in any medium, provided the original work is properly cited.

\begin{abstract}
The poultry industry has a significant importance on national economy. It is a popular industry for the small holders with tremendous contribution to Gross Domestic Product (GDP) and employment creation. Poultry feed cost represents over sixty (60) percent of the total cost of poultry production; consequently, efficient feed formulation practice is required for a sustainable poultry industry. Many Ghanaian poultry farmers, however, employ inefficient methods like rule of thumb, experiences, and intuition to handle feed formulation problem. This paper presents a deterministic linear programming model to solve blending problem facing poultry farmers, using locally available feed ingredients from the Ghanaian poultry industry. In the model, we shall minimize cost of producing a particular diet and maintain the ingredient. Over 3\% reductions in the cost of producing broiler starter and finisher feed formulation compared to the existing method on the farm was achieved.
\end{abstract}

Keywords: Gross Domestic Product (GDP); Poultry Feed; Deterministic Linear Programming Model; Rule of Thumb; Blending Problem.

\section{Introduction}

With the exception of urban areas, most poultry production in Ghana is undertaken through the extensive farm system at the family level. This poultry provides a good source of protein and ready cash. The financial gains in turn help to sustain the family economy. However, this type of poultry production suffers from the constraints of feeding practice and overall production management, which normally increase the production cost unduly. The production cost, is normally affected by managerial cost, labour cost, inventory cost, transportation cost, cost of drugs, housing and electricity, feeding cost, etc. It has been reported that the feeding cost alone takes about sixty to seventy (60-70) per cent of the total production cost, which is of major concern to the local farmers, GPPR, [3] This situation obviously reduces the amount of animal protein the Poultry farmers could have produced for human consumption. The problem is recognized as optimizing cost factor, which depends on constraints (ingredients of the feed) and could be solved by Deterministic Linear Programming Model, (DLPM) or Mixed Integer Programming, (MIP).

Annetts and Audsley [1] developed an MILP model to solve the problem of planning farming systems where environmental resources were declining. Their objective was to identify the best crop and machinery options which are profitable. This resulted in improvements of the environment, potential crop yields, and soil and farm profit.

Mohammed and Said [5] developed an LP crop mix model for a finite-time planning horizon. Given limited available resources such as budget and land acreage, the crop-mix planning model was formulated and transformed into a multiperiod linear programming problem. The objective was to maximize the total returns at the end of the finite-time planning horizon.

The purpose of this paper is to do quantitative analysis of the poultry feed mix and thus develop a mathematical model for blending the poultry feed mix to minimize the feeding cost in the poultry production. 


\section{Linear programming and blending problem}

A Linear Programming (LP) is one of the most widely used optimization techniques and perhaps the most effective. The term Linear Programming was coined by George Dantzig in 1947 to refer to problems in which both the objective function and constraints are linear as proposed by [2].

A Linear Programming is the problem of optimizing linear objective in the decision variables $X_{1}, X_{2}, \ldots \ldots \ldots . . . X_{n}$ subject to linear equality or inequality constraints on the X's.

Standard form of Linear Programming is;

Maximize $\mathrm{F}=\sum_{j=1}^{n} C_{j} X_{j}$

Subject to

$\sum_{j=1}^{n} a(i, j) X_{j}=b_{i}, i=1,2, \ldots, n$

$l_{j} \leq X_{j} \leq u_{j}, \mathrm{j}=1,2 \ldots, \mathrm{n}$

Where $C_{j}$ are the n objective function. Coefficients, $a(i, j)$ and $b_{j}$ are parameters in the m linear inequality constraints and $l_{j}$ and $u_{j}$ are lower and upper bounds with $l_{j} \leq u_{j}$. Both $l_{j}$ and $u_{j}$ may be positive or negative.

\subsection{Blending problems}

Blending problems arise whenever a manager is to decide how to combine two or more ingredients in order to produce one or more products. These types of problems occur frequently in the petroleum industry (such as blending crude oil to produce different octane gasoline) and the chemical industry (such as blending chemicals to produce fertilizers, weed killers), and so on. In these applications, managers should decide how much of each resource to purchase in order to satisfy product specifications and product demands at a minimum cost.

\section{Formulation of LP model}

Mathematical models were constructed for starter and finisher types of broiler ration using limited ingredients. The objective of the models was to minimize cost of producing a particular diet after satisfying a set of constraints. These constraints were mainly those from nutrient requirements of the birds and ingredient constraints by [6]. The variables in the models were the ingredients while the cost of each ingredient and the nutrient value of each ingredient was the parameter as described by [4]. The specified LP model for the attainment of the objective function is:

Minimize $Z=\sum C_{i j} X_{j}$

Where $\mathrm{Z}=$ Total cost of the ration, $\mathrm{Cj}=$ Ingredient cost, $j=1,2,3, \ldots, m$

$X_{i}=$ Ingredients quantity, $i=1,2,3, \ldots, n$

Subject to

$$
\begin{aligned}
& x_{1}+x_{2}+x_{3}+\ldots+x_{8}=b_{1} \\
& a_{11} x_{1}+a_{12} x_{2}+a_{13} x_{3}+\ldots+a_{18} x_{8} \leq b_{2} \\
& a_{21} x_{1}+a_{22} x_{2}+a_{23} x_{3}+\ldots+a_{28} x_{8} \leq b_{3} \\
& a_{31} x_{1}+a_{32} x_{2}+a_{33} x_{3}+\ldots+a_{38} x_{8} \leq b_{4} \\
& a_{41} x_{1}+a_{42} x_{2}+a_{43} x_{3}+\ldots+a_{48} x_{8} \leq b_{5} \\
& a_{51} x_{1}+a_{52} x_{2}+a_{53} x_{3}+\ldots+a_{58} x_{8} \leq b_{6}
\end{aligned}
$$




$$
\begin{aligned}
& a_{61} x_{1}+a_{62} x_{2}+a_{63} x_{3}+\ldots+a_{68} x_{8} \leq b_{7} \\
& a_{71} x_{1}+a_{72} x_{2}+a_{73} x_{3}+\ldots+a_{78} x_{8} \leq b_{8} \\
& a_{81} x_{1}+a_{82} x_{2}+a_{83} x_{3}+\ldots+a_{88} x_{8} \leq b_{9} \\
& a_{91} x_{1}+a_{92} x_{2}+a_{93} x_{3}+\ldots+a_{98} x_{8} \leq b_{10} \\
& a_{101} x_{1}+a_{102} x_{2}+a_{103} x_{3}+\ldots+a_{108} x_{8} \leq b_{11} \\
& x_{i} \geq 0, i=1,2,3, \ldots, n
\end{aligned}
$$

Where ai $=$ Technical coefficients of nutrient components in feedstuffs, $\mathrm{bi}=$ Constraints of the ration.

Assumptions

The assumptions made in formulating the LP model include:

i) All the projects and constraints are independent on one another.

ii) Equal investment opportunities are assumed for the projects for each period.

iii) The cash flows, resources and constraints are known with certainty.

\section{Data collection and analysis}

Secondary data were collected from the recommended nutrient requirements' schedule from Birds and Veterinary Service; Ghana limited for the study. Feedstuffs used in ration formulation for poultry farms in Dormaa Municipality include maize $\left(\mathrm{x}_{1}\right)$, soyaabeann $\left(\mathrm{x}_{2}\right)$, wheat bran $\left(\mathrm{x}_{3}\right)$, fish meal $\left(\mathrm{x}_{4}\right)$, lysine $\left(\mathrm{x}_{5}\right)$, concentrate $\left(\mathrm{x}_{6}\right)$, premix $\left(\mathrm{x}_{7}\right)$, cotton $\left(\mathrm{x}_{8}\right)$, oyster shell $\left(\mathrm{x}_{9}\right)$ and methionine $\left(\mathrm{x}_{10}\right)$. Cost implications of feedstuffs and nutrient levels of feed ingredients, constraints imposed on the selection of feedstuffs for broiler rations and least-cost formulation restrictions on nutrients were collated. Ten (10) decision variables and eight (8) constraints were identified and used for the LP model for least cost rations for broilers, (Tables 1, 2, 3, and 4).

Table 1: Cost Implications of Feedstuffs and Nutrient Levels of Feed Ingredients

\begin{tabular}{llllllllll}
\hline Nutrients & $\begin{array}{l}\text { Cost } \\
(\mathrm{GH} \phi) /\end{array}$ & $\begin{array}{l}\text { Crude } \\
\text { protein } \\
(\%)\end{array}$ & $\begin{array}{l}\text { Fat } \\
(\%)\end{array}$ & $\begin{array}{l}\text { Crude } \\
\text { fiber } \\
(\%)\end{array}$ & $\begin{array}{l}\text { Calcium } \\
(\%)\end{array}$ & $\begin{array}{l}\text { Phosphorus } \\
(\%)\end{array}$ & $\begin{array}{l}\text { Lysine } \\
(\%)\end{array}$ & $\begin{array}{l}\text { Methionine } \\
(\%)\end{array}$ & $\begin{array}{l}\text { Me } \\
(\mathrm{k} / \mathrm{cal}) \\
(\%)\end{array}$ \\
\hline $\mathrm{x} 1$ & 0.70 & 8.8 & 4.0 & 2.0 & 0.1 & 0.34 & 0.4 & 0.18 & 3432 \\
$\mathrm{x} 2$ & 1.40 & 48 & 3.5 & 6.5 & 0.2 & 0.37 & 3.2 & 0.59 & 2557 \\
$\mathrm{x} 3$ & 2.00 & 13 & 0 & 5.1 & 0.05 & 1.20 & 0.5 & 0.42 & 3153 \\
$\mathrm{x} 4$ & 1.80 & 60 & 4.5 & 1.0 & 6.5 & 3.5 & 4.5 & 1.8 & 2950 \\
x5 & 7.00 & 95 & 0 & 0 & 0 & 0 & 100 & 0 & 0 \\
x6 & 2.60 & 12 & 0.25 & 4.75 & 1.50 & 1.50 & 0.2 & 0.15 & 1260 \\
x7 & 3.00 & 0 & 0 & 0 & 0 & 0 & 0 & 0 & 0 \\
x8 & 1.40 & 39.6 & 0 & 0 & 0.15 & 0.48 & 62.8 & 71.9 & 2350 \\
x9 & 0.24 & 0 & 0 & 0 & 38 & 0 & 0 & 0 & 0 \\
x10 & 5.00 & 60 & 0 & 0 & 0 & 0 & 0 & 10 & 0 \\
\hline
\end{tabular}

Table 2: Constraint Imposed On the Selection of Feedstuffs for Starter Broiler Rations

\begin{tabular}{lll} 
& Table 2: Constraint Imposed On the Selection of Feedstuffs for Starter Broiler Rations \\
\hline Nutrients & Maximum level & Minimum level \\
\hline Crude protein (\%) & - & 23 \\
ME(Kcal/kg) & 3200 & 2800 \\
Calcium $(\%)$ & 15 & 10 \\
Phosphorus $(\%)$ & - & 45 \\
Fat $(\%)$ & 50 & - \\
Crude fiber $(\%)$ & 50 & - \\
Lysine $(\%)$ & - & 11 \\
Methionine $(\%)$ & - & 5 \\
\hline
\end{tabular}


Table 3: Constraint Imposed On the Selection of Feedstuffs for Finisher Broiler Rations

\begin{tabular}{lll}
\hline Nutrients & Maximum level & Minimum level \\
\hline Crude protein (\%) & - & 18 \\
ME(Kcal/kg) & 3400 & 3200 \\
Calcium $(\%)$ & 25 & 10 \\
Phosphorus $(\%)$ & - & 55 \\
Fat $(\%)$ & 60 & - \\
Crude fiber (\%) & 50 & - \\
Lysine (\%) & - & 11 \\
Methionine $(\%)$ & - & 5 \\
\hline
\end{tabular}

Table 4: Least-Cost Formulation Restrictions on Nutrients and Feedstuffs for Broiler Rations

\begin{tabular}{lll}
\hline Item & Starter stage & Finisher stage \\
\hline Weight $(\mathrm{kg})$ & 1000 & 1000 \\
Crude protein $(\%)$ & $\leq 23$ & $\leq 18$ \\
ME(Kcal/kg) & $\leq 2800$ & $\leq 3200$ \\
Calcium $(\%)$ & $\geq 15$ & $\leq 10$ \\
Phosphorus $(\%)$ & $\leq 45$ & $\leq 45$ \\
Fat (\%) & $\geq 50$ & $\geq 60$ \\
Crude fiber & $\geq 50$ & $\geq 50$ \\
Lysine $(\%)$ & $\leq 11$ & $\leq 11$ \\
Methionine $(\%)$ & $\leq 5$ & $\leq 5$ \\
\hline
\end{tabular}

\section{LP model implementation}

The model is implemented in two ways:

i) LP Model for least cost starter ration

ii) LP Model for least cost finisher ration

\subsection{Implementation of LP model for the least cost starter ration}

Substituting the various ingredients in the tables 1 and 3 into the model, we have

$\operatorname{Min}(Z)=0.7 x_{1}+1.4 x_{2}+2 x_{3}+1.8 x_{4}+7 x_{5}+2.6 x_{6}+3 x_{7}+1.4 x_{8}+0.24 x_{9}+5 x_{10}$

Subject to:

$$
\begin{aligned}
& x_{1}+x_{2}+x_{3}+x_{4}+x_{5}+x_{6}+x_{7}+x_{8} \leq 1000 \\
& 8.8 x_{1}+48 x_{2}+13 x_{3}+60 x_{4}+95 x_{5}+12 x_{6}+39.6 x_{8} \leq 23 \\
& 4 x_{1}+3.5 x_{2}+4.5 x_{3}+0.25 x_{6} \leq 5 \\
& 2 x_{1}+6.5 x_{2}+5.1 x_{3}+1 x_{4}+4.75 x_{6} \leq 5 \\
& 0.1 x_{1}+0.2 x_{2}+0.05 x_{3}+6.5 x_{4}+1.5 x_{6}+0.15 x_{8}+38 x_{9} \leq 1.5 \\
& 0.34 x_{1}+0.37 x_{2}+1.2 x_{3}+3.5 x_{4}+1.5 x_{6}+0.48 x_{8} \leq 0.45 \\
& 0.40 x_{1}+3.2 x_{2}+0.5 x_{3}+4.5 x_{4}+100 x_{5}+0.2 x_{6}+62.8 x_{8} \leq 1.51 \\
& 0.18 x_{1}+0.59 x_{2}+0.42 x_{3}+1.8 x_{4}+0.15 x_{6}+71.9 x_{8}+100 x_{10} \leq 0.5 \\
& 3432 x_{1}+2557 x_{2}+3153 x_{3}+2950 x_{4}+1260 x_{6}+2350 x_{8} \leq 2800 \\
& x_{1}, x_{2}, x_{3}, x_{4}, x_{5}, x_{6}, x_{7}, x_{8}, x_{9}, x_{10} \geq 0
\end{aligned}
$$


Table 5: Solution to LP Model for Least Cost Starter Ration, Using Matlab Package

\begin{tabular}{lllll}
\hline Decision variable & Variable solution & Unit Cost & Total Cost & Reduced Cost \\
\hline Maize (x1) & 517 & 0.70 & 361.90 & -11.90 \\
Soya bean (x2) & 356.7 & 1.40 & 499.38 & -219.38 \\
Wheat bran (x3) & 0 & 2.00 & 0.00 & 146.00 \\
Fish meal (x4) & 0 & 1.80 & 0.00 & 144.00 \\
Lysine (x5) & 1.40 & 7.00 & 9.80 & -2.80 \\
Concentrate (x6) & 90.0 & 2.60 & 234.00 & -52.00 \\
Premix (x7) & 1.00 & 3.00 & 3.00 & 0.00 \\
Cotton (x8) & 0 & 1.40 & 0.00 & 35.00 \\
Oyster shell (x9) & 32.7 & 0.24 & 7.85 & 4.15 \\
Methionine (x10) & 1.8 & 5.00 & 9.00 & -4.00 \\
Total Reduction Cost & & & & 39.07 \\
\hline
\end{tabular}

From Table 5, the quantity of wheat bran, fish meal and cotton were reduced to zero $(0 \mathrm{~kg})$ since almost the nutritional value they offer can also be found in the other ingredients (constraints). The quantity of maize, soya bean, lysine, concentrate and methionine were increased in order to supplement for the nutritional value that the wheat bran, fish meal and cotton would have offered. The quantity of oyster shell was reduced, and the quantity of premix was obtained in order to balance the nutritional level of the feed. This model reduces the feed cost by almost Gh $\$ 39.00$.

\subsection{Implementation of LP model for the least cost finisher ration}

Applying the various ingredients in tables 1 and 3 into the LP model, yields

$\operatorname{Min}(Z)=0.7 x_{1}+1.4 x_{2}+2 x_{3}+1.8 x_{4}+7 x_{5}+2.6 x_{6}+3 x_{7}+1.4 x_{8}+0.24 x_{9}+5 x_{10}$

Subject to:

$x_{1}+x_{2}+x_{3}+x_{4}+x_{5}+x_{6}+x_{7}+x_{8} \leq 1000$

$8.8 x_{1}+48 x_{2}+13 x_{3}+60 x_{4}+95 x_{5}+12 x_{6}+39.6 x_{8} \leq 21$

$4 x_{1}+3.5 x_{2}+4.5 x_{3}+0.25 x_{6} \leq 6$

$2 x_{1}+6.5 x_{2}+5.1 x_{3}+1 x_{4}+4.75 x_{6} \leq 5$

$0.1 x_{1}+0.2 x_{2}+0.05 x_{3}+6.5 x_{4}+1.5 x_{6}+0.15 x_{8}+38 x_{9} \leq 1.5$

$0.34 x_{1}+0.37 x_{2}+1.2 x_{3}+3.5 x_{4}+1.5 x_{6}+0.48 x_{8} \leq 0.45$

$0.40 x_{1}+3.2 x_{2}+0.5 x_{3}+4.5 x_{4}+100 x_{5}+0.2 x_{6}+62.8 x_{8} \leq 1.51$

$0.18 x_{1}+0.59 x_{2}+0.42 x_{3}+1.8 x_{4}+0.15 x_{6}+71.9 x_{8}+100 x_{10} \leq 0.5$

$3432 x_{1}+2557 x_{2}+3153 x_{3}+2950 x_{4}+1260 x_{6}+2350 x_{8} \leq 3200$

$x_{1}, x_{2}, x_{3}, x_{4}, x_{5}, x_{6}, x_{7}, x_{8}, x_{9}, x_{10} \geq 0$

Table 6: Solution to LP Model for Least Cost Finisher Ration, Using Matlab Package

\begin{tabular}{lllll}
\hline Decision variable & Variable solution & Unit Cost & Total Cost & Reduced Cost \\
\hline Maize (x1) & 696.4 & 0.70 & 487.48 & -46.48 \\
Soya bean (x2) & 84.9 & 1.40 & 118.86 & 91.14 \\
Wheat bran (x3) & 0 & 2.00 & 0.00 & 60.00 \\
Fish meal (x4) & 0 & 1.80 & 0.00 & 45.00 \\
Lysine (x5) & 0 & 7.00 & 0.00 & 17.50 \\
Concentrate (x6) & 168.7 & 2.60 & 438.62 & -139.62 \\
Premix (x7) & 1.00 & 3.00 & 3.00 & 0.00 \\
Cotton (x8) & 0 & 1.40 & 0.00 & 5.60 \\
Oyster shell (x9) & 46.7 & 0.24 & 11.21 & -1.61 \\
Methionine (x10) & 3.3 & 5.00 & 16.50 & -0.50 \\
Total Reduction Cost & & & & 31.03 \\
\hline
\end{tabular}


From Table 6, the quantity of wheat bran, fish meal, lysine and cotton were reduced to zero (0kg) since almost the nutritional value they offer can also be found in the other ingredients (constraint). The quantity of maize, concentrate, oyster shell and methionine were increased in order to supplement for the nutritional value that the wheat bran, fish meal, lysine and cotton would have offered. The quantity of soya bean was reduced and the quantity of premix was obtained in order to balance the nutritional level of the feed. This model reduces the feed cost by almost Gh\$31.03.

\subsection{Least cost starter and finisher rations compared with existing practice}

The existing practices for both starter and finisher ration were compared with the mathematical model for both starter and finisher ration to see which one is more cost effective. The results were recorded in tables 7 and 8.

Table 7: Least Cost Starter Ration versus Existing Practice

\begin{tabular}{llllll}
\hline \multirow{2}{*}{ Ingredient $(\mathrm{xj})$} & \multirow{2}{*}{ Cost $(\mathrm{GH} \not) / \mathrm{kg}$} & \multicolumn{2}{c}{ Exiting practice } & \multicolumn{2}{c}{ Proposed solution } \\
\cline { 3 - 6 } & & Value $(\mathrm{kg})$ & Cost $(\mathrm{GH} \phi)$ & Value $(\mathrm{kg})$ & Cost $(\mathrm{GH} \phi)$ \\
\hline Maize & 0.70 & 500 & 350.00 & 517 & 361.90 \\
Soya bean & 1.40 & 200 & 280.00 & 356.7 & 499.38 \\
Wheat bran & 2.00 & 73 & 146.00 & 0 & 0.00 \\
Fish meal & 1.8 & 80 & 144.00 & 0 & 0.00 \\
Lysine & 7.00 & 1 & 7.00 & 1.4 & 9.80 \\
Concentrate & 2.60 & 70 & 182.0 & 90 & 3.00 \\
Premix & 3.00 & 1 & 3.00 & 1 & 0.00 \\
Cotton & 1.40 & 25 & 35.00 & 0 & 7.85 \\
Oyster shell & 0.24 & 50 & 12.00 & 32.7 & 9.00 \\
Methionine & 5.00 & 1 & 5.00 & 1.8 & 1124.93 \\
Objective function value & 1001 & 1164.00 & 1000.6 & \\
\hline
\end{tabular}

The cost of producing broiler starter feed is Gh $\$ 1164.00$ using the existing practice of the farm compared with the $\mathrm{Gh} \$ 1124.93$ if feed formulation is based on the proposed mathematical model. This gives a substantial savings of about $3.36 \%$. Obviously feed formulation is more cost effective when based on valid Linear programming model.

Table 8: Least Cost Finisher Ration versus Existing Practice

\begin{tabular}{llllll}
\hline \multirow{2}{*}{ Ingredient $(\mathrm{xj})$} & \multirow{2}{*}{ Cost $(\mathrm{GH} \phi) / \mathrm{kg}$} & \multicolumn{2}{c}{ Exiting practice } & \multicolumn{2}{c}{ Proposed solution } \\
\cline { 3 - 6 } & & Value $(\mathrm{kg})$ & Cost $(\mathrm{GH} \phi)$ & \multicolumn{1}{c}{ Value $(\mathrm{kg})$} & Cost $(\mathrm{GH} \phi)$ \\
\hline Maize & 0.70 & 630 & 441.00 & 696.4 & 487.48 \\
Soya bean & 1.40 & 150 & 210.00 & 84.9 & 118.86 \\
Wheat bran & 2.00 & 30 & 60.00 & 0 & 0.00 \\
Fish meal & 1.8 & 25 & 45.00 & 0 & 0.00 \\
Lysine & 7.00 & 2.5 & 17.50 & 0 & 0.00 \\
Concentrate & 2.60 & 115 & 299.00 & 168.7 & 338.62 \\
Premix & 3.00 & 1 & 3.00 & 1 & 3.00 \\
Cotton & 1.40 & 4 & 5.60 & 0 & 0.00 \\
Oyster shell & 0.24 & 40 & 9.60 & 46.7 & 11.21 \\
Methionine & 5.00 & 3.2 & 16.00 & 3.3 & 16.5 \\
Objective function value & 1000.7 & 1106.70 & 1001 & 1075.67 \\
\hline
\end{tabular}

The cost of producing broiler finisher feed is Gh $\$ 1106.70$ using the existing practice of the farm compared with the $\mathrm{Gh} \$ 1075.67$ if feed formulation is based on the proposed LP model. This results in substantial savings of about $2.80 \%$. Feed formulation is more cost-effective than the existing farm practice.

\section{Conclusions}

The total reduction cost by the linear programming model for the least cost starter ration is Gh $\$ 39.00$ per ton representing $11 \%$ reduction in broiler starter feed formulations compared with the cost of the existing method on the farm. Whilst the total reduction cost by the linear programming model for the least cost finisher ration is Gh $₫ 31.03$ per ton representing $3 \%$ reduction in broiler finisher feed formulation.

Furthermore, the least-cost diet formulation produced by linear programming model showed that the starter ration consists of $51.7 \%$ maize, $35.67 \%$ soya bean, $0.14 \%$ lysine, $9 \%$ concentrate, $0.1 \%$ premix, $3.27 \%$ oyster shell and $0.18 \%$ methionine. This ration meets all the nutritional requirements needed for starter broiler. The cost of the ration is Gh\$1124.93 per ton. 
For the finisher ration the results showed $69.64 \%$ maize, $8.49 \%$ soya bean, $16.87 \%$ concentrate, $0.1 \%$ premix, $4.67 \%$ oyster shell and $0.33 \%$ methoinine ingredients. The cost of the ration is Gh $\$ 1106.70$ per ton.

\section{References}

[1] Annetts J. E. and Audsley E. (2002). Multiple Objectives Linear Programming for Environmental Farm Planning. Journal of the Operational Research Society, 53, 933-943. http://dx.doi.org/10.1057/palgrave.jors.2601404.

[2] Dantzig (1998) and Martin, (1999). Analysis of Mathematical Programming Problems Prior to Applying the Simplex Method. 'Mathematical Programming, $54-83$.

[3] Ghana Poultry and Products Report, (GPPR), (2011). USDA Foreign Agricultural Service.

[4] Hiller, F. S., Lieberman G. J. and Liebeman G., (1995). Introduction to Operations Research, New York: McGraw Hill.

[5] Mohammed N. H. J. and Said F. (2001). A Mathematical Programming Approach to Crop Mix Problem. African journal of Agricultural Research, 6(1), 191-197.

[6] Munford, A.G. (1996). The Use of Mathematical Programming in Practical Applications of Animal Diet Formulation. Mathematics and Computers in Simulation 42: 255-261. http://dx.doi.org/10.1016/0378-4754(95)00115-8. 